J. Clin. Chem. Clin. Biochem.

Vol. 19. 1981, pp. 1103-1106

\title{
Direct Spectrophotometric Determination of Serum and Urinary Oxalate with Oxalate Oxidase ${ }^{1}$ )
}

\author{
By G. Kohlbecker
}

Institut für Molekularbiologie und Biochemie, Freie Universität Berlin and

M. Butz

Urologische Klinik und Poliklinik, Klinikum Steglitz, Freie Universität Berlin

(Received May 20, 1981)

Summary: A new enzymatic method for direct photometric determination of oxalate in serum and urine is described, using oxalate oxidase. The resulting $\mathrm{H}_{2} \mathrm{O}_{2}$ is measured with a coupled enzyme system of catalase and aldehyde dehydrogenase. Percentage recovery of added oxalate was $99 \pm 4$ in serum, and $98 \pm 4$ in urine $(n=10)$. Oxalate serum levels varied from 16.9 to $44.8 \mu \mathrm{mol} / 1$. Oxalate values can be determined within 20 minutes, without time consuming pretreatment of samples. The detection limit is $5 \mu \mathrm{mol} / 1$.

\section{Direkte spektrophotometrische Bestimmung von Serum- und Urin-Oxalat mit Oxalat-Oxidase}

Zusammenfassung: Es wird eine neue enzymatische Methode zur direkten photometrischen Bestimmung von Oxalat in Serum und Urin mittels Oxalatoxidase beschrieben. In einer gekoppelten Reaktion wird $\mathrm{H}_{2} \mathrm{O}_{2}$ enzymatisch durch Katalase und Aldehyddehydrogenase gemessen. Die Wiederfindung von zugesetztem Oxalat betrug $99 \pm 4 \%$ in Serum und $98 \pm 4 \%$ in Urin $(n=10)$. Die Oxalatkonzentrationen in Serum variierten von 16,9 bis $44,8 \mu \mathrm{mol} / 1$. Oxalatwerte können ohne zeitraubende Probenvorbehandlung innerhalb 20 Minuten ermittelt werden. Die Erfassungsgrenze liegt bei $5 \mu \mathrm{mol} / 1$.

\section{Introduction}

Reliable measurement of oxalate is required in the investigation of calcium urolithiasis and various intestinal diseases with enteric hyperoxaluria. In the majority of published methods for oxalate determination, extraction or precipitation steps are necessary. Moreover, known methods lack specifity (2).

There are two possible enzymatic reactions for the degradation of oxalate: Decarboxylation by oxalate decarboxylase (oxalate carboxy-lyase, EC 4.1.1.2) and oxidation by oxalate oxidase (oxalate: oxygen oxidoreductase, EC 1.2.3.4). The former reaction has been used by various authors (3-8), but has proved unsuitable for routine purposes. The latter reaction was introduced by the present authors in $1978(9,10)$.

There are various approaches to the measurement of the degradation products, $\mathrm{CO}_{2}$ and $\mathrm{H}_{2} \mathrm{O}_{2}$. If $\mathrm{CO}_{2}$ is measured, the assay is twice as sensitive as that based on the decarboxylation (11). However, there are difficulties in the determination of oxalate in serum, especially with regard to the high endogeneous concentration of $\mathrm{CO}_{2}$. We therefore evaluated various $\mathrm{H}_{2} \mathrm{O}_{2}$ assays. The catalase/ aldehyde dehydrogenase reaction for $\mathrm{H}_{2} \mathrm{O}_{2}$ determination (12) is widely accepted in laboratory practice because of its specifity. We coupled this reaction with the oxidation of oxalate (10), and in the present paper we have adapted the procedure for a simple and quick determination of oxalate in serum and urine:

$$
\begin{aligned}
& (\mathrm{COOH})_{2}+\mathrm{O}_{2} \stackrel{\text { oxalate oxidase }}{\longrightarrow} 2 \mathrm{CO}_{2}+\mathrm{H}_{2} \mathrm{O}_{2} \\
& \mathrm{H}_{2} \mathrm{O}_{2}+\text { ethanol } \stackrel{\text { catalase }}{\longrightarrow} \text { acetaldehydc }+2 \mathrm{H}_{2} \mathrm{O} \\
& \text { acetaldehyde }+\mathrm{NADP}^{+} \frac{\text { aldehyde }}{\text { dehydrogenase }}+\mathrm{H}^{+} \\
& +\mathrm{H}_{2} \mathrm{O}
\end{aligned}
$$

\section{Material and Methods}

Reagents

Catalase (hydrogen peroxide: hydrogen peroxide oxidoreductase, EC 1.11.1.6): Boehringer Mannheim No. 106810.

\footnotetext{
1) Parts of this publication were presented at an international meeting in London, 1979 (1).
} 
Aldehyde dehydrogenase (aldehyde: NAD(P)oxidoreductase, EC 1.2.1.5): Sigma No. A 6758 ( $\mathrm{K}^{+}$-activated from baker's yeast).

Oxalate oxidase (oxalate: oxygen oxidoreductase, EC 1.2.3.4), was isolated from barley seedlings (13). After extraction with $\mathrm{H}_{2} \mathrm{O}$, contaminating proteins were removed by heat denaturation and fractional ammonium sulfate precipitation (45-65\% saturation). The enzyme.was further purified by ion exchange chromatography on DEAE-Sephadex A-50, with imidazole buffer, $\mathrm{I}=0.05, \mathrm{pH} 8$ and elution with a $\mathrm{NaCl}$ gradient. From $1 \mathrm{~kg}$ seedlings we obtained $6 \mathrm{mg}$ enzyme protein free of protease and catalase with a specific activity of about $15 \mathrm{U} / \mathrm{mg}\left(37^{\circ} \mathrm{C}\right.$, $50 \mathrm{mmol} / 1$ succinate buffer $\mathrm{pH} 3.8$ ). Partially purified enzyme preparations containing catalase activity are also suitable for oxalate determination by the aldehyde dehydrogenase method, but for reasons of stability they should not contain protease. The preparation was stable as a solution $(2 \mathrm{~g} / \mathrm{l})$ in $5 \mathrm{mmol} / \mathrm{l}$ succinate buffer $\mathrm{pH} 3.8$ containing $5 \mathrm{mmol} / 1$ EDTA and $20 \mathrm{mg} / \mathrm{l}$ merthiolate for at least 6 months at $4{ }^{\circ} \mathrm{C}$. Commercially available enzyme can also be used (Boehringer Mannheim No. 567698).

NADP $^{+}$: Boehringer Mannheim No. 127353.

All other chemicals were obtained as p. a. grade from Merck (Darmstadt).

\section{Equipment}

Instruments from Eppendorf Gerätebau GmbH (Hamburg) were used: Photometer $1101 \mathrm{M}$ with recorder.

Ultrafilter cones Centriflo CF 25 were purchased from Amicon $\mathrm{GmbH}$ (Witten).

\section{Solutions}

1: Succinate ( $5 \mathrm{mmol} / \mathrm{l})$ buffer pH $3.8+5 \mathrm{mmol} / 1$ EDTA: Dissolve $590 \mathrm{mg}$ succinic acid $+1.86 \mathrm{~g}$ EDTA in about $900 \mathrm{ml}$ $\mathrm{H}_{2} \mathrm{O}$, adjust $\mathrm{pH}$ to 3.8 with $\mathrm{NaOH}$ and adjust to 11 with $\mathrm{H}_{2} \mathrm{O}$.

2: This solution is prepared fresh daily:

$16 \mathrm{ml}$ ethanol and $500 \mu \mathrm{l}(=650 \mathrm{kU})$ catalase are added to $100 \mathrm{ml}$ solution 1 .

3: Diphosphate $(180 \mathrm{mmol} / \mathrm{l})$ buffer $\mathrm{pH} 9.0+90 \mathrm{mmol} / \mathrm{l} \mathrm{KCl}$ : Dissolve $80.2 \mathrm{~g} \mathrm{Na}_{4} \mathrm{P}_{2} \mathrm{O}_{7} \cdot 10 \mathrm{H}_{2} \mathrm{O}+6.71 \mathrm{~g} \mathrm{KCl}$ in about $900 \mathrm{ml}$ $\mathrm{H}_{2} \mathrm{O}$, adjust $\mathrm{pH}$ to 9.0 with $\mathrm{HCl}$ and adjust to 11 with $\mathrm{H}_{2} \mathrm{O}$.

4: This solution is prepared fresh daily:

$1 \mathrm{~g}$ NADP in added to 11 solution 3.

5: Oxalate oxidase: $500 \mathrm{mg} / 1$ in solution 1 .

6: Aldehyde dehydrogenase: $7.5 \mathrm{kU} / 1 \mathrm{H}_{2} \mathrm{O}$.

Sample pretreatment

Urine

Either fresh or stored ( $\mathrm{HCl}$ preserved) urine is diluted in a proportion of 1:10 with succinate buffer containing EDTA (solution 1).

\section{Serum}

Proteins with molecular weights above 25000 are removed by ultrafiltration. About $3 \mathrm{ml}$ serum are transferred to ultrafilter cones and rotated for $3 \mathrm{~min}$ at $750 \mathrm{~g}$. Under these conditions, approx. $1.5 \mathrm{ml}$ of protein-free ultrafiltrate with no decrease in the oxalate concentration are obtained. $\mathrm{pH}$ is adjusted to a value between 3.5 and 4.5 with $10 \mu 12 \mathrm{~mol} / 1 \mathrm{HCl}$ per $1 \mathrm{ml}$ ultrafiltrate.

\section{Procedure (tab. 1)}

The reaction buffer, containing EDTA, ethanol and catalase, is transferred to sample and blank vessels. The sample (diluted urine or deprotemized serum) is added to both, the blank and the sample vessel, and the reaction in the sample vessel is started by addition of oxalate oxidase. Hydrogen peroxide, from the oxidation of the oxalate, oxidizes ethanol to acetaldehyde in the presence of catalase.

$15 \mathrm{~min}$ later, the $\mathrm{pH}$ is made alkaline by adding a buffer solution of $\mathrm{pH} 9$, containing the coenzyme NADP $\mathrm{P}^{+}$. The indicator reaction is started by aldehyde dehydrogenase. Acetaldehyde, generated in the first reaction step, is now oxidized to acetate; this oxidation
Tab. 1. Assay procedure.

Sample: either serum ultrafiltrate or diluted $(1: 10)$ urine

\begin{tabular}{lcc}
\hline & Sample & Blank \\
& $(\mu l)$ & $(\mu 1)$ \\
\hline Solution 2 & 150 & 150 \\
Sample & 50 & 50 \\
Oxalate oxidase, solution 5 & 10 & - \\
Solution 1 & - & 10 \\
Incubate 15 min at approx. $20^{\circ} \mathrm{C}$ & & \\
Solution 4 & 200 & 200 \\
Aldehyde dehydrogenase, solution 6 & 10 & 10 \\
\hline
\end{tabular}

Read $\Delta A_{334}^{d=2} \mathrm{~nm}$ of sample against blank after at least $3 \mathrm{~min}$ $\left(\mathrm{A}_{1}\right)$.

In order to eliminate the absorbance value of oxalate oxidase, an additional $10 \mu \mathrm{l}$ oxalate oxidase are pipetted into a sample vessel, and the resulting absorbance difference $\left(\mathbf{A}_{2}\right)$, which can be used for all samples, is subtracted from every sample: $\mathbf{A}_{1}-\mathbf{A}_{2}=\mathbf{A}_{3}$.

Calculation:

Urine $\quad c=\mathrm{A}_{3} \cdot 6800(\mu \mathrm{mol} / \mathrm{l})$

Serum ultrafiltrate $c=A_{3} \cdot 680(\mu \mathrm{mol} / \mathrm{l})$

(Molar lineic absorbance: $\underset{\epsilon 344 \mathrm{~nm}}{\mathrm{NADPH}}=6.18 \cdot 10^{3} \mathrm{1} \cdot \mathrm{mol}^{-1} \cdot \mathrm{cm}^{-1}$ $=618 \mathrm{~m}^{2} \cdot \mathrm{mol}^{-1}$ ).

is coupled with the reduction of NADP+ $\mathrm{NADPH}^{+}$equimolecular with the original oxalate, is measured photometrically at $334 \mathrm{~nm}$. The sample value is read against a blank. The oxalate concentration is calculated from the absorbance value without reference to a standard solution.

When the oxidation of acetaldehyde is finished, a continuous increase of absorbance is observed, which varies between individual samples. This nonspecific increase of absorbance can be quantitatively reduced, if $\mathrm{NADP}^{+}$is used instead of $\mathrm{NAD}^{+}$. Nevertheless, the use of a recorder is advisable and allows extrapolation of the absorbance reading to the start of the aldehyde dehydrogenase reaction (fig. 1 )

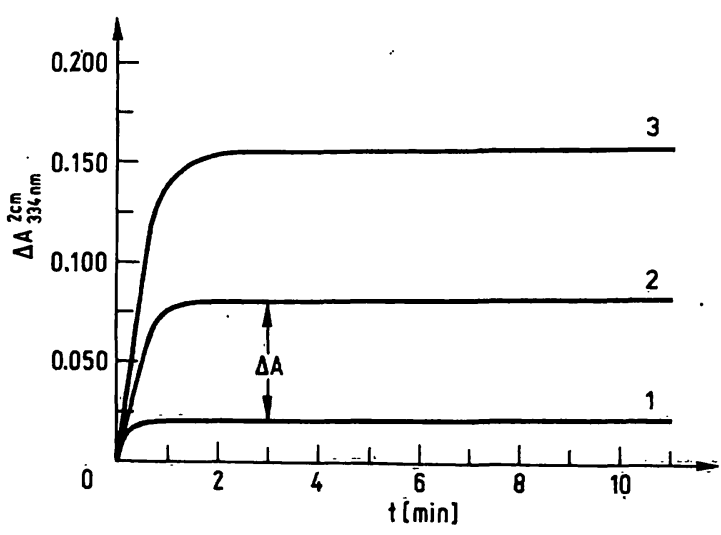

Fig. 1. Reaction kinetics of a serum ultrafiltrate measurement. Simultaneous recording of the absorbance of 1) blank, 2) sample, 3) sample with 2.5 nmol oxalate added. Oxalate concentration $c=680 \cdot \Delta \mathrm{A}=3.9 .4 \mu \mathrm{mol} / 1$ sample. Recovery of added oxalate: $2.45 \mathrm{nmol}=98 \%$. 


\section{Results}

We determined the following values as criteria of the method:

\section{Limit of detection}

Using the method of Kaiser (14), the detection limit was calculated from the spread of blank values (threefold standard deviation). For serum this is $5 \mu \mathrm{mol} / 1$, for urine $20 \mu \mathrm{mol} / 1$.

\section{Specificity}

The enzyme oxalate oxidase is strictly specific for oxalate. No other substrates have been found. The majority of $\mathrm{H}_{2} \mathrm{O}_{2}$ assays are disturbed by reducing agents such as ascorbic acid. Ascorbic acid was added in varying concentrations to urine samples. Ascorbate concentrations in the range tested $(0-5 \mathrm{mmol} / \mathrm{l})$ had no influence on the measured oxalate concentration.

However, a nonspecific increase of absorbance, which was independent of the specific acetaldehyde dehydrogenase reaction, was observed. The slope of this increase correlates to the ascorbate concentration in the sample. If ascorbate oxidase (EC 1.10.3.3) is added, this absorbance phenomenon is not detectable. It should be noted that the measured oxalate concentration is not altered, as blank and sample have identical absorbance slopes.

\section{Accuracy}

\section{Linearity}

In a concentration range of $0-8 \mathrm{nmol}$ oxalate/sample linearity is observed (fig. 2). For serum $(50 \mu \mathrm{l})$ the corresponding final concentration range is $0-160 \mu \mathrm{mol} / 1$, for urine $(5 \mu \mathrm{l}) 0-1.6 \mathrm{mmol} / \mathrm{l}$.

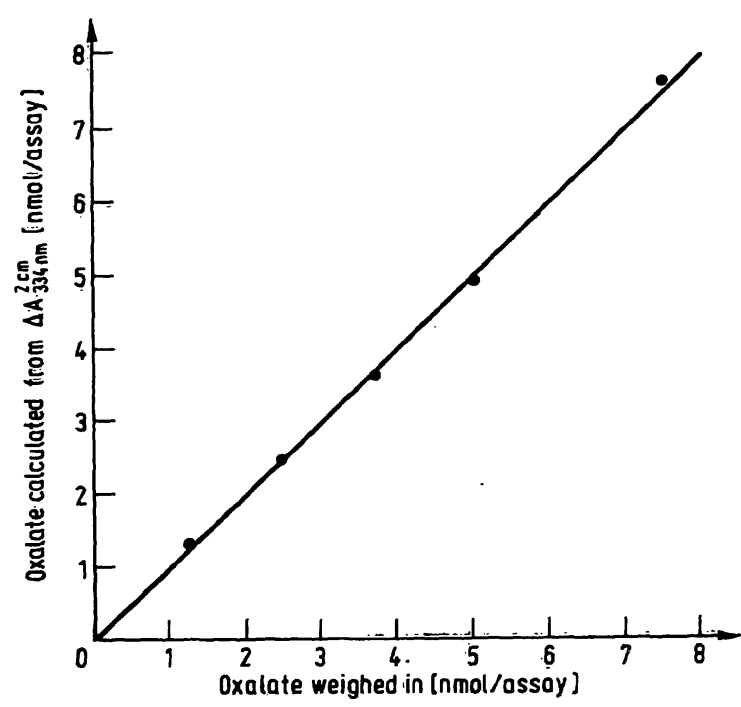

Fig. 2. Correlation between different concentrations of oxalate in aqueous solutions and the amount of oxalate found. Analysis of regression: $y=1.0106 x-0.0284(n=5)$ $\bar{x}=4.00, \bar{y}=4.01, r=0.9988$

\section{Recovery}

To analyzed samples, $2.5 \mathrm{nmol}$ of oxalate were added. Recovery in urine was $98 \pm 4 \%(n=10)$, in serum $99 \pm 4 \%(n=10)($ tab. 2$)$.

Tab. 2. Oxalate concentration of urine and serum samples and analytical recovery of oxalate added.

$2.5 \mathrm{nmol}$ oxalate were added to the previously analyzed samples and oxalate concentrations were measured again.

\begin{tabular}{lllll}
\hline Sample & $\begin{array}{l}\text { Urine } \\
\text { Oxalate } \\
\text { concentra- } \\
\text { tion }\end{array}$ & $\begin{array}{l}\text { Recovery } \\
\text { of } 2.5 \text { nmol } \\
\text { oxalate } \\
\text { added }\end{array}$ & $\begin{array}{l}\text { Serum } \\
\text { Oxalate } \\
\text { concentra- } \\
\text { tion }\end{array}$ & $\begin{array}{l}\text { Recovery } \\
\text { of } 2.5 \text { nmol } \\
\text { oxalate added }\end{array}$ \\
& $(\mu \mathrm{mol} / \mathrm{l})$ & $(\%)$ & $(\mu \mathrm{mol} / \mathrm{l})$ & $(\%)$ \\
\hline 1 & 143 & 100 & 33.6 & 96 \\
2 & 298 & 95 & 31.8 & 101 \\
3 & 145 & 103 & 33.9 & 103 \\
4 & 347 & 97 & 40.3 & 98 \\
5 & 476 & 99 & 16.9 & 102 \\
6 & 200 & 94 & 23.4 & 99 \\
7 & 177 & 102 & 44.8 & 104 \\
8 & 363 & 91 & 39.2 & 98 \\
9 & 238 & 95 & 28.7 & 92 \\
10 & 309 & 104 & 35.5 & 101 \\
\hline$\overline{\mathbf{x}} \pm \mathrm{SD}$ & $270 \pm 108$ & $98 \pm 4$ & $32.8 \pm 8$ & $99 \pm 4$ \\
\hline
\end{tabular}

\section{Comparison of methods}

In 8 urine samples, oxalate was analyzed either by measurement of $\mathrm{CO}_{2}$ (11) or the method described. The coefficient of correlation was 0.9530 (fig. 3).

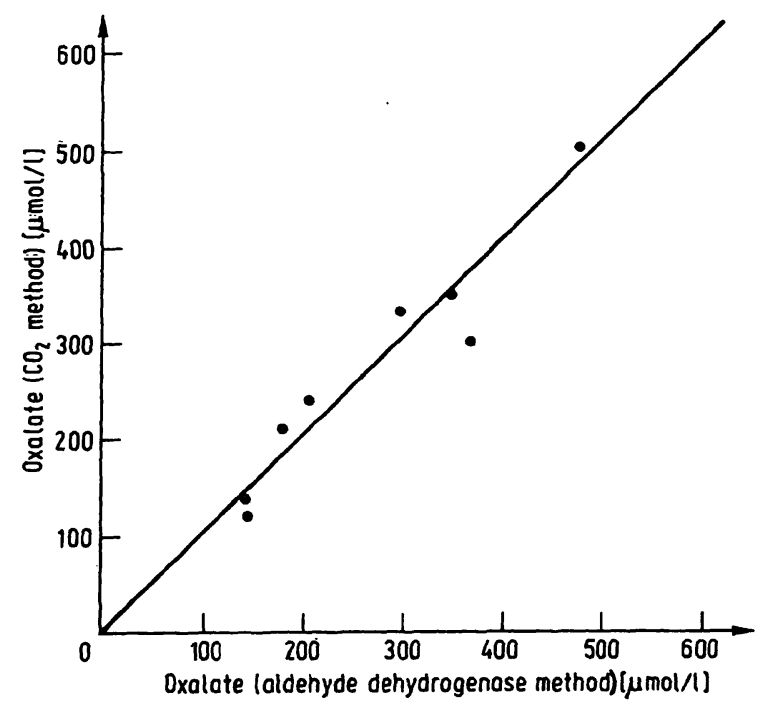

Fig. 3. Comparison of oxalate concentrations found in various urine samples as measured by the present aldehyde dehydrogenase method and a $\mathrm{CO}_{2}$ method (11). Regression analysis: $y=0.9995 x+6.7504(n=8)$ $\bar{x}=269, \bar{y}=275, \quad r=0.9530$ 


\section{Reproducibility $(n=10)$}

\section{Serum}

The reproducibility among a series was $35.4 \pm 1.1 \mu \mathrm{mol} / 1$ $(\mathrm{CV}=3.1 \%)$, from day to day $34.3 \pm 1.3 \mu \mathrm{mol} / \mathrm{l}(\mathrm{CV}=$ $3.8 \%)$.

\section{Urine}

The reproducibility among a series was $200 \pm 9 \mu \mathrm{mol} / 1$ $(\mathrm{CV}=4.5 \%)$, from day to day $203 \pm 12(\mathrm{CV}=5.9 \%)$.

\section{Discussion}

There is general agreement on the fundamental disadvantages of any method for the estimation of oxalate, which is based on extraction of the oxalate. Direct measurement of oxalate in urine as well as in serum is possible by the use of oxalate oxidase.

We formerly ruled out various possibilities for the estima. tion of the $\mathrm{H}_{2} \mathrm{O}_{2}$ produced in the oxalate oxidation (9, $10)$. In comparison with colorimetric methods $(15,16)$, reactions coupled with $\mathrm{NAD}^{+} / \mathrm{NADP}^{+}$seem to be advantageous. According to Haeckel (17) the catalase/aldehyde dehydrogenase reaction for the estimation of $\mathrm{H}_{2} \mathrm{O}_{2}$ is highly specific. Sixty compounds that often occur in serum and urine were shown not to interfere. Especially ascorbic acid might be expected to disturb $\mathrm{H}_{2} \mathrm{O}_{2}$-producing reactions, because of its high physiological concentration in urine. We demonstrated that ascorbic acid has no influence on the measured oxalate concentration in urine. The detection limit of the method also permits the estimation of serum oxalate. There is still

\section{References}

1. Kohlbecker, G. \& Butz, M. (1979) In: Oxalate in Human Biochemistry and Clinical Pathology. (Rose, G. A., Robertson, W. G. \& Watts, R. W. E. eds.): Proceedings of an international meeting in London on 26th and 27th October, 1979, Wellcome Foundation London, pp. 87-89.

2. Hodgkinson, A. (1978) Oxalic Acid in Biology and Medicine, Academic Press, London 1978, 360 pp.

3. Crawhall, J. C. \& Watts, R. W. E. (1961) Clin. Sci. 20, $357-$ 366.

4. Mayer, G. G., Markow, D. \& Karp, F. (1963) Clin. Chem. 9 , 334-339.

5. Knowles, C. F. \& Hodgkinson, A. (1972) Analyst 97, 474481.

6. Hallson, P. C. \& Rose, G. A. (1974) Clin. Chim. Acta 55, 29-39.

7. Costello, J., Hatch, M. \& Bourke, E. (1976) J. Lab. Clin. Med. 87, 903-908.

8. Hatch, M., Bourke, E. \& Costello, J. (1977) Clin. Chem. 23, $76-78$.

9. Kohlbecker, G., Butz, M. \& Heinz, F. (1978) Proc. X. Int Congr. Clin. Chem., Mexico City 1978, 107. much controversy (2) about the true oxalate value in serum and its significance with regard to disturbancies of oxalate metabolism (18) or urolithiasis (19).

The serum values measured by our method can be compared to those obtained by Hatch et al. (8) with a different enzymatic method. To us, sample pretreatment seems to be a crucial point. Ultrafiltration has proved to be a reliable method for serum deproteinization. According to our experiments with $\left[{ }^{14} \mathrm{C}\right]$ oxalate and those of other authors (20), oxalate is freely filtrable at a physiological $\mathrm{pH}$. There is no need for alkalinization as described by others (8).

The enzymatic method commonly used for determination of urinary oxalate is that introduced by Hallson \& Rose (6). Using modified reaction vessels and substituting decarboxylase by oxidase, we achieved higher sensitivity and accuracy for the method (11). However, oxalate can only be measured after an incubation time of at least 16 hours.

In contrast, the spectrophotometric approach of measuring $\mathrm{H}_{2} \mathrm{O}_{2}$ allows estimation of oxalate within $20 \mathrm{~min}$ utes. Thus, larger series are feasible, especially as a calibration curve is not necessary. The concentration can be calculated directly, using the lineic molar absorbance of $\mathrm{NADPH}$.

\section{Acknowledgements}

We are indebted to Mrs. Lieselotte Richter for excellent technical assistance. The valuable constant advice from Prof. Dr. F. Heinz, Medizinische Hochschule Hannover, is gratefully acknowledged.

10. Kohlbecker, G. (1978) Offenlegungsschrift P 2806371.0 , Dt. Patentamt München, 10. 2. 1978.

11. Kohlbecker, G., Richter, L. \& Butz, M. (1979) J. Clin. Chem. Clin. Biochem. 17, 309-313.

12. Haeckel, R. \& Heinz, F. (1975) Z. Klin. Chem. Biochem. 13, 244.

13. Chiriboga, J. (1966) Arch. Biochem. Biophys. 116, 516-523.

14. Kaiser, H. (1965) Z. Analyt. Chem. 209, 1-18.

15. Laker, M. F., Hofmann, A. F. \& Meeuse, B. J. D. (1980) Clin. Chem. 26, 827-830.

16. Sugiura, M., Yamamura, H., Hirano, K., Ito, Y., Sạsaki, M., Morikawa, M., Inoue, M. \& Tsuboi, M. (1980) Clin. Chim. Acta 105, 393-399.

17. Haeckel, R. (1976) J. Clin. Chem. Clin. Biochem. 14, 101107.

18. Butz, M., Hoffmann, H. \& Kohlbecker, G. (1980) Urol. Int. $35,309-315$.

19. Butz, M. \& Kohlbecker, G. (1980) Urol. Int. 35, 303-308.

20. Chambers, M. M. \& Russell, J. C. (1973) Clin. Biochem. 6, $22-28$.

Priv.-Doz. Dr. M. Butz Urologische Klinik und Poliklinik Klinikum Steglitż

Freie Universität Berlin

Hindenburgdamm 30

D-1000 Berlin 45 